\title{
ДОСЛІДЖЕННЯ ГІДРОКСИКОРИЧНИХ КИСЛОТ ПІДЗЕМНИХ ОРГАНІВ КАТРАНУ СЕРЦЕЛИСТОГО ТА КАТРАНУ КОКТЕБЕЛЬСЬКОГО
}

Вступ. Piд Crambe L. (Катран) належить до родини хрестоцвіті (Brassicaceae) і налічує 44 види. У фрлорі України знаходиться 8 видів роду Crambe L., у степовій зоні росте 6. Наукова назва роду походить від грецького слова "krambos", що означає "сухий”. У народній медицині катрани здавна застосовували як антибактеріальний, антивірусний, протицинготний, ранозагоювальний засіб. Катрани відомі в основному як пряно-овочева культура. Вегетативну частину рослини цінують у тваринництві як поживний корм для великої та дрібної худоби, а насіння катрану, що містить до 45 \% жирної олії, слугує сировиною для отримання технічного масла, воску, різних паливно-мастильних матеріалів. Отже, рід Crambe L. $\epsilon$ перспективним завдяки його харчовим, декоративним та лікарським властивостям тощо. Рослини Сrambe належать до лікарських культур, хоча не входять до фрармакопейних списків офріційної медицини. Рослини роду Катран вивчено мало. Тому актуальним є дослідження біологічно активних речовин двох видів роду Катран - катрану серцелистого (Crambe cordifolia Stev.) та катрану коктебельського (Crambe koktebelica (Junge) N. Busch), які зумовлюють його фрармакологічну активність.

Мета дослідження - встановити наявність і визначити кількісний вміст гідроксикоричних кислот у підземних органах катрану серцелистого та катрану коктебельського методом високоефективної рідинної хроматографії (BEPX).

Методи дослідження. Вміст фенольних сполук визначали методом ВEPX.

Результати й обговорення. Методом ВEPX у підземних органах катрану серцелистого та катрану коктебельського виявлено, ідентифріковано і встановлено кількісний вміст хлорогенової, кофейної, сирінгової, р-кумарової, транс-фрерулової, синапової, транс-цинамової кислот. У коренеплодах катрану серцелистого, крім вищенаведених, ідентифріковано хінну кислоту. В сировині обох видів катрану не виявлено галової, гідроксифенілоцтової і транс-фрерулової кислот. Домінувала в підземних органах катрану серцелистого та катрану коктебельського хлорогенова кислота, вміст якої становив 421,6 і 278,4 мкг/г відповідно.

Висновки. Встановлено наявність і методом ВEPX-аналізу визначено кількісний вміст у підземних органах катрану серцелистого та катрану коктебельського індивідуальних гідроксикоричних кислот хлорогенової, кофрейної, р-кумарової, сирінгової, синапової, транс-цинамової, а в підземних органах катрану серцелистого - також хінної. З'ясовано, що у досліджуваній сировині обох видів катрану домінує хлорогенова кислота, вміст якої становить 421,6 і 278,4 мкг/2 відповідно.

КЛЮЧОВІ СЛОВА: катран серцелистий; катран коктебельський; підземні органи; гідроксикоричні кислоти; високоесективна рідинна хроматографрія.

ВСТУП. Рід Crambe L. (Катран) належить до родини хрестоцвіті (Brassicaceae) і налічує 44 види [1-3]. Це одно-, дво- або багаторічні трав'янисті рослини, які можуть проростати як на рівні моря, так і на висоті 3800 м у Гімалаях, яку помірно морських, так і в напівсухих та сухих кліматичних умовах. У фрлорі України знаходиться 8 видів роду Crambe L., у степовій зоні росте 6 [4]. Наукова назва роду походить від грецького слова "krambos", що означає "сухий".

3 існуючих у дикій природі численних видів роду Катран найбільшого поширення набули: катран степовий, катран східний або татарський; катран приморський; катран абіссінський (вирощують як олійну і кормову культуру) та катран (с) О. Я. Скринчук, С. М. Марчишин, Л. В. Слободянюк, М. М. Когут, 2020. серцелистий (застосовують у садово-парковому дизайні для бордюрних посадок).

У народній медицині катрани здавна застосовували як антибактеріальний, антивірусний, протицинготний, ранозагоювальний засіб. Їх використовують для поліпшення травлення і підвищення апетиту, для загоєння ран, виведення веснянок, як замінник гірчичників (кашка 3 коренеплоду). Завдяки значному вмісту вітаміну С у листках рослини, катрани застосовують як прекрасний засіб, що запобігає цинзі.

Катрани відомі в основному як пряно-овочева культура. 3 листків деяких видів готують салати, їх використовують при виготовленні соусів, маринадів, засолюванні огірків, помідорів, грибів $[2,4]$. 
Вегетативну частину рослини цінують у тваринництві як поживний корм для великої та дрібної худоби [4], а насіння катрану, що містить до 45 \% жирної олії, слугує сировиною для отримання технічного масла, воску, різних паливно-мастильних матеріалів $[5,6]$.

Отже, рід Crambe L. є перспективним завдяки його харчовим, декоративним та лікарським властивостям тощо [4].

Рослини Crambe належать до лікарських культур, хоча не входять до фармакопейних списків офріційної медицини.

Рослини роду Катран вивчено мало. $€$ лише поодинокі повідомлення про дослідження хімічного складу деяких видів роду Crambe. Тому актуальним $€$ дослідження біологічно активних речовин двох видів роду Катран - катрану серцелистого (Crambe cordifolia Stev.) та катрану коктебельського (Crambe koktebelica (Junge) N. Busch), які зумовлюють його фрармакологічну активність.

Мета дослідження - встановити наявність i визначити кількісний вміст гідроксикоричних кислот у підземних органах катрану серцелистого та катрану коктебельського методом високоесрективної рідинної хроматографрії (BEPX).

МЕТОДИ ДОСЛІДЖЕННЯ. Об'єКТОМ ДЛЯ досліджень були підземні органи (коренеплоди) катрану серцелистого та катрану коктебельського, які заготовляли на дослідних ділянках Національного ботанічного саду ім. М. М. Гришка НАН України (м. Київ) 2020 р. після відмирання надземної частини рослин.

Для виявлення френолкарбонових кислот використовували спиртово-водну витяжку. Реакція з $1 \%$ розчином фрерум (III) хлориду (поява зелено-сірого забарвлення) свідчила про наявність у досліджуваній витяжці сполук френольної природи.

Якісний склад та кількісний вміст гідроксикоричних кислот у досліджуваній сировині досліджували методом ВЕРХ на хроматографрі Agilent Technologies 1200 . Як рухому фразу використовували метанол (А) та 0,1 \% розчин мура- шиної кислоти у воді (В). Елюювання проводили в градієнтному режимі: 0 хв - А (25 \%) : В (75\%); 25 XB - A (75\%) : B (25\%); 27 XB - A (100\%) : В (0 \%); 35 ХВ - А (100\%) : В (0 \%). Розділення здійснювали на хроматографрічній колонці Zorbax SB-Aq (4,6 мм \pm 150 мм, 3,5 мкм) (Agilent Technologies, США), швидкість потоку через колонку 0,5 мл/хв, температура термостата $-30^{\circ} \mathrm{C}$, об'єм інжекції-4 мкл. Детекцію проводили, використовуючи діодно-матричний детектор, із реєстрацією сигналу при 250 та 275 нм та фріксацією спектрів поглинання в діапазоні 210-700 нм [7].

Підготовка проб для аналізу: наважку сировини (0,1-1,0 г) екстрагували 5-10 мл $60 \%$ розчину метанолу на ультразвуковій бані при $80^{\circ} \mathrm{C}$ упродовж 4 год у скляних герметичних віалах із тефлоновою кришкою. Отриманий екстракт центрисугували при 3 тис. об./хв та фрільтрували крізь одноразові мембранні фрільтри з порами 0,22 мкм.

Ідентифрікацію та кількісний аналіз проводили з використанням стандартних розчинів фе-нольних сполук (галової, гідроксифенілоцтової, хлорогенової, кофейної, сирінгової, $p$-кумарової, транс-срерулової, синапової, транс-цинамової, хінної кислот).

Вміст сполук (Х) (мкг/г) визначали за фрормулою:

$$
\mathrm{X}=\mathrm{c} \cdot \mathrm{V} / \mathrm{m} \text {, }
$$

де с - концентрація сполуки, визначена хроматографрічно, мкг/мл;

$\mathrm{V}$ - об'єм екстракту, мл;

m - маса сировини, з якої проводили екстракцію, г [7, 8].

РЕЗУЛЬТАТИ Й ОБГОВОРЕННЯ. МетОДОМ ВЕРХ у підземних органах катрану серцелистого та катрану коктебельського виявлено, ідентифіковано і встановлено кількісний вміст хлорогенової, кофейної, сирінгової, р-кумарової, синапової, транс-цинамової кислот. У коренеплодах катрану серцелистого, крім вищенаведених, ідентисріковано хінну кислоту. Результати досліджень наведено в таблиці й на рисунках 1 і 2.

Таблиця - Якісний склад і кількісний вміст індивідуальних гідроксикоричних кислот у підземних органах катрану серцелистого та катрану коктебельського

\begin{tabular}{||l|c|c|c||}
\hline \multirow{2}{*}{\multicolumn{1}{|c|}{ Назва речовини }} & УФ-спектр $\lambda$ max, & \multicolumn{2}{c|}{ Кількісний вміст, мкг/г } \\
\cline { 3 - 4 } & нм & катран серцелистий & катран коктебельський \\
\hline Кислота хлорогенова & 275 & 421,6 & 278,4 \\
\hline Кислота косрейна & 275 & 64,4 & 49,8 \\
\hline Кислота р-кумарова & 275 & 6,7 & $41 / 4$ \\
\hline Кислота сирінгова & 275 & 10,3 & 33,6 \\
\hline Кислота синапова & 275 & 107,9 & 44,7 \\
\hline Кислота транс-цинамова & 275 & 18,0 & 9,3 \\
\hline Кислота хінна & 275 & 79,1 & H/в \\
\hline
\end{tabular}

Примітка. н/в - не виявлено. 


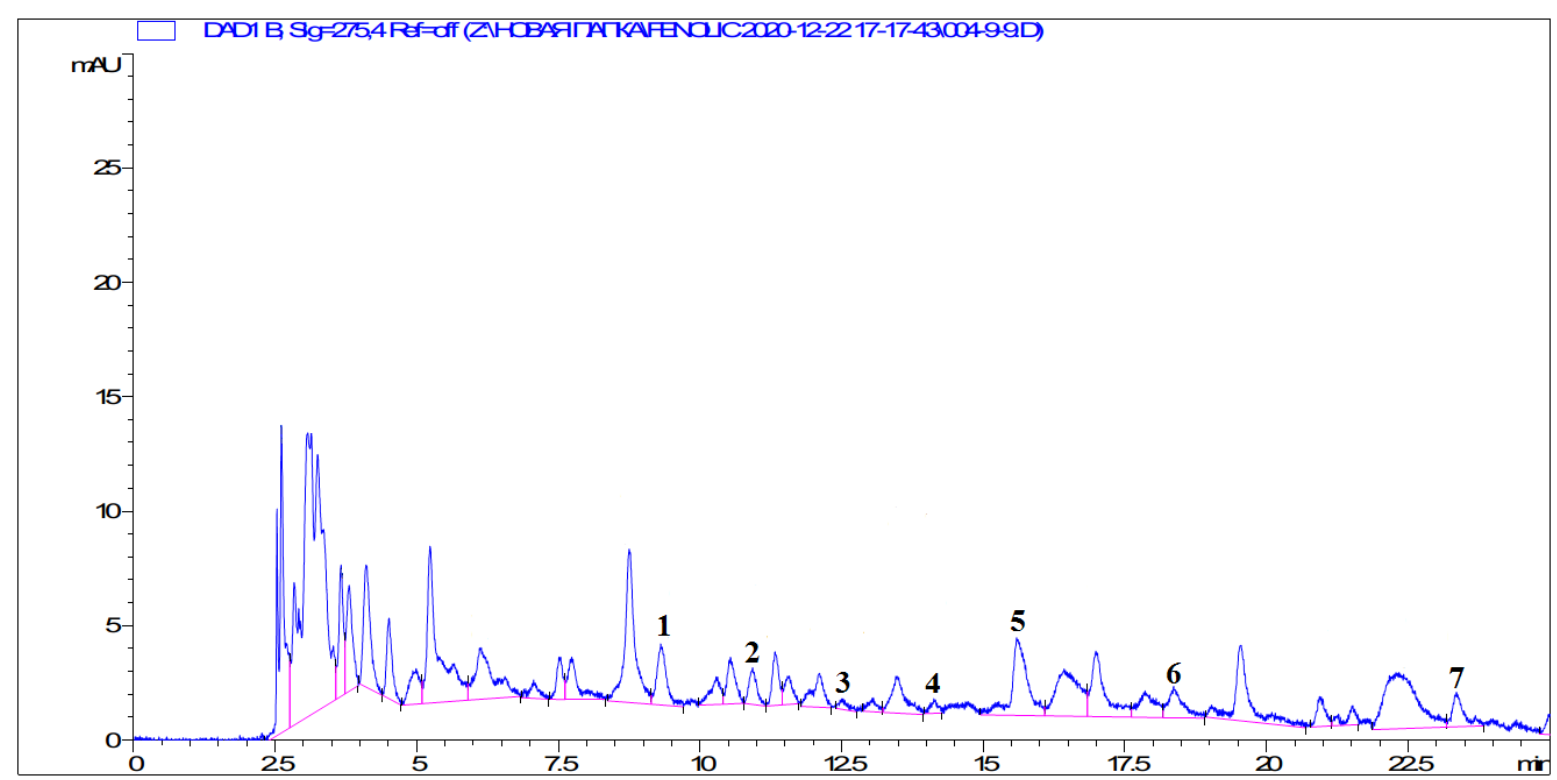

Рис. 1. ВЕРХ-хроматограма спиртово-водної витяжки підземних органів катрану серцелистого при $\lambda=275$ нм: $1-$ хлорогенова, 2 - кофейна, 3 - сирінгова, 4 - p-кумарова, 5 - синапова, 6 - транс-цинамова, 7 - хінна кислоти.

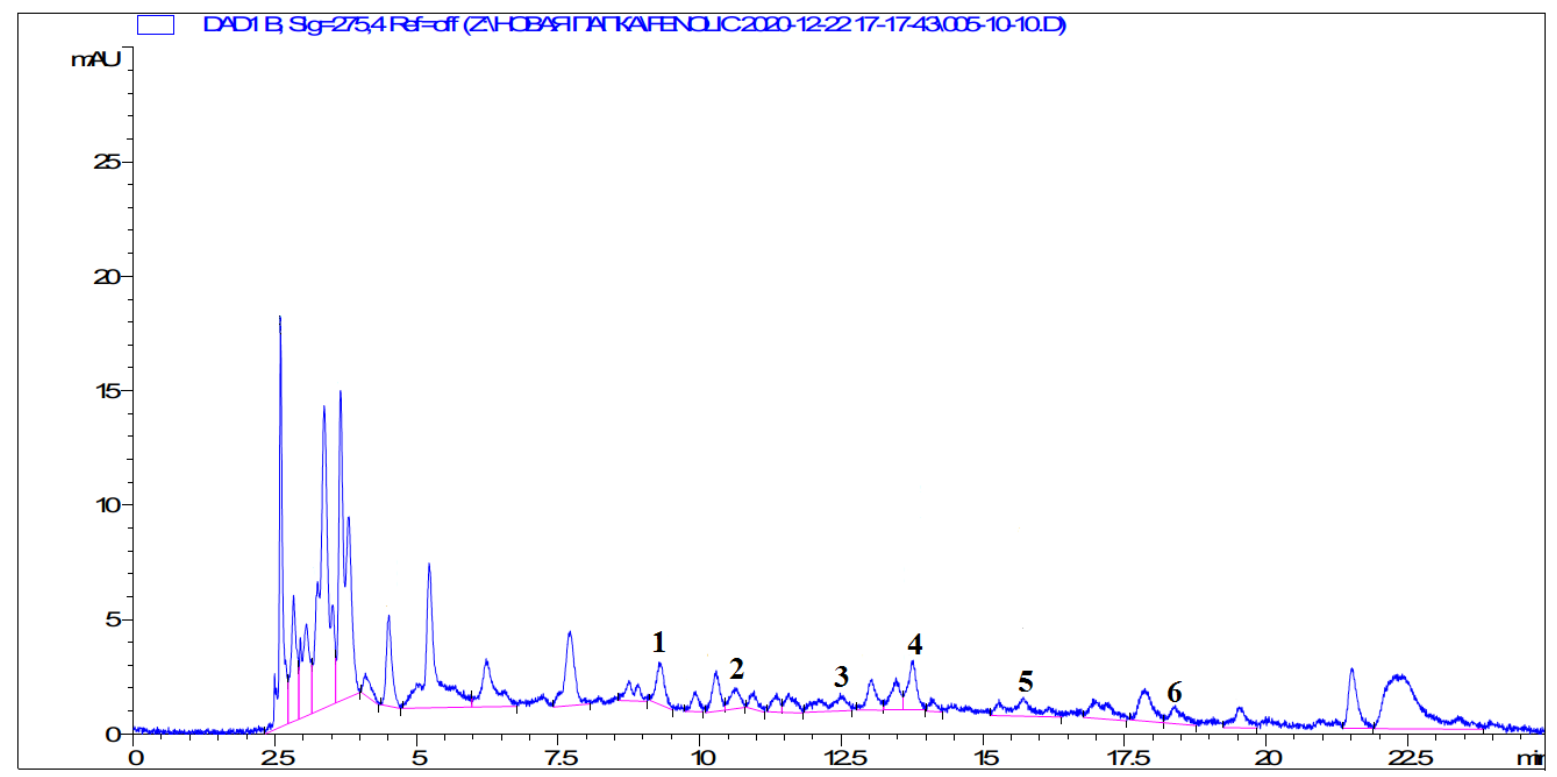

Рис. 2. ВЕРХ-хроматограма спиртово-водної витяжки підземних органів катрану коктебельського при $\lambda=275$ нм: 1 хлорогенова, 2 - кофейна, 3 - сирінгова, 4 - p-кумарова, 5 - синапова, 6 - транс-цинамова кислоти.

Результати досліджень показали, що у сировині обох видів катрану не виявлено галової, гідроксифенілоцтової і транс-фрерулової кислот. Домінувала в підземних органах катрану серцелистого та катрану коктебельського хлорогенова кислота, вміст якої становив 421,6 і 278,4 мкг/г відповідно.

ВИСНОВКИ. 1. Встановлено наявність і методом BEPX-аналізу визначено кількісний вміст у підземних органах катрану серцелистого та катрану коктебельського індивідуальних гідроксикоричних кислот -хлорогенової, кофейної, р-кумарової, сирінгової, синапової, транс-цинамової, а в підземних органах катрану серцелистого - також хінної.

2. З'ясовано, що у досліджуваній сировині катрану серцелистого та катрану коктебельського домінує хлорогенова кислота, вміст якої становить 421,6 і 278,4 мкг/г відповідно. 


\section{СПИСОК ЛІТЕРАТУРИ}

1. The accumulation of nutrients in under-ground parts of plants of the genus Crambe L. spp / O. M. Vergun, D. B. Rakhmetov, O. V. Shymanska, V. V. Fishchenko // Інтродукція рослин. - 2018. - No. 2. - Р. 3-11.

2. Заверуха Б. В. Квіти дванадцяти місяців / Б. В. Заверуха. - К. : Урожай, 1986. - 176 с.

3. Branca F. Brassica. Wild Crop Relatives: Genomic and Breeding Resources. Oilseeds / F. Branca, E. Cartea. - ed. C. Kole. - Heidelberg: Springer, 2011. P. 17-36.

4. Kalista M. Underutilized medicinal species of Crambe L. of the flora of Ukraine / M. Kalista // Agrobiodiversity for Improving Nutrition, Health and Life Quality. 2017. - No. 1. - P. 216-220.

5. Physiological quality and enzymatic activity of crambe seeds after the accelerated aging test / M. Z. To- ledo, R. N. Teirxeira, T. B. Ferrari [et al.] // Acta Scientia Rum. Agronomy. - 2011. - 33, No. 4. - P. 687-694.

6. Study of the methyl crambe (Crambe abyssinica Hochst) and soybean biodiesel oxidative stability I W. T. Wzilewski, R. A. Bariccatti, G. I. Martins [et al.] // Industrial Crops and Products. - 2013. - 43. - P. 207-210.

7. Sumere B. R. Combining pressurized liquids with ultrasound to improve the extraction of phenolic compounds from pomegranate peel (Punica granatum L.) // Ultrasonics Sonochemistry. - 2018. - 48. - P. 151-162.

8. Марчишин С. М. Дослідження кислот гідроксикоричних трави чистецю Зібольда / С. М. Марчишин, Л. В. Гусак, Т. С. Бердей // Мед. та клініч. хімія. -2016. 18, № 3 (68). - С. 13-16.

\section{REFERENCES}

1. Vergun, O.M., Rakhmetov, D.B., Shymanska, O.V., \& Fishchenko, V.V. (2018). The accumulation of nutrients in under-ground parts of plants of the genus Crambe $\mathrm{L}$. spp. Introduktsiia rolyn - Introduction of Plants, 2, 3-11.

2. Zaverukha, B.V. (1986). Kvity dvanadtsiaty misiatsiv [Flowers of twelve months]. Kyiv: Urozhai [in Ukrainian].

3. Branca, F., \& Cartea, E. (2011). Brassica. Wild Crop Relatives: Genomic and Breeding Resources. Oilseeds. Kole, C. (Ed.). Heidelberg: Springer.

4. Kalista, M. (2017). Underutilized medicinal species of Crambe L. of the flora of Ukraine. Agrobiodiversity for Improving Nutrition, Health and Life Quality, 1, 216-220.

5. Toledo, M.Z., Teirxeira, R.N., \& Ferrari, T.B. (2011). Physiological quality and enzymatic activity of crambe seeds after the accelerated aging test. Acta Scientia Rum. Agronomy, 33 (4), 687-694.

6. Wzilewski, W.T., Bariccatti, R.A., Martins, G.I., Secco, D., Rosa, H.A., Chaves, L.I. (2013). Study of the methyl crambe (Crambe abyssinica Hochst) and soybean biodiesel oxidative stability. Industrial Crops and Products, 43, 207-210.

7. Sumere, B.R. (2018). Combining pressurized liquids with ultrasound to improve the extraction of phenolic compounds from pomegranate peel (Punica granatum L.). Ultrasonics Sonochemistry, 48, 151-162.

8. Marchyshyn, S.M., Husak, L.V., \& Berdei, T.S. (2016). Doslidzhennia kyslot hidroksykorychnykh travy chystetsiu Zibolda [Research of hydroxycinnamic acids of Japanese artichoke]. Med. ta klin. khimiia - Medical and Clinical Chemistry, 18 (3), (68), 13-16 [in Ukrainian].

О. Я. Скринчук, С. М. Марчишин, Л. В. Слободянюк, М. М. Когут

ТЕРНОПОЛЬСКИЙ НАЦИОНАЛЬНЫЙ МЕДИЦИНСКИЙ УНИВЕРСИТЕТ ИМЕНИ И. Я. ГОРБАЧЕВСКОГО МОЗ УКРАИНЫ

\section{ИССЛЕДОВАНИЕ ГИДРОКСИКОРИЧНЫХ КИСЛОТ ПОДЗЕМНЫХ ОРГАНОВ КАТРАНА СЕРДЦЕЛИСТНОГО И КАТРАНА КОКТЕБЕЛЬСКОГО}

\section{Резюме}

Вступление. Род Crambe L. (Катран) принадлежит к семейству крестоцветные (Brassicaceae) и насчитывает 44 вида. Во фрлоре Украины находится 8 видов рода Crambe L., в степной зоне растет 6. Научное название рода происходит от греческого слова "krambos", что означает "сухой". В народной медицине катраны издавна применяли как антибактериальное, антивирусное, противоцинготное, ранозаживляющее средство. Катраны известны в основном как пряно-овощная культура. Вегетативную часть растения ценят в животноводстве как питательный корм для крупного и мелкого скота, а семена катрана, содержащие до 45 \% жирного масла, служат сырьем для получения технического масла, воска, различных горюче-смазочных материалов. Итак, род Crambe L. является перспективным благодаря его пищевым, декоративным и лекарственным свойствам и m. п. Растения Crambe принадлежат к лекарственным культурам, хотя не входят в фрармакопейные списки официальной медицины. Растения рода Катран изучено мало. Поэтому актуальным является исследование биологически активных веществ двух видов рода Катран - катрана сердцелистного (Crambe cordifolia Stev.) и катрана коктебельского (Crambe koktebelica (Junge) N. Busch), которые обусловливают его фрармакологическую активность. 
Цель исследования - установить наличие и определить количественное содержание гидроксикоричных кислот в подземных органах катрана сердцелистного и катрана коктебельского методом высокоэфорективной жидкостной хроматографиии (ВЭЖХ).

Методы исследования. Содержание френольных соединений определяли методом ВЭЖХ.

Результаты и обсуждение. Методом ВЭЖХ в подземных органах катрана сердцелистного и катрана коктебельского обнаружено, идентифицировано и установлено количественное содержание хлорогеновой, кофейной, сиринговой, р-кумаровой, транс-фреруловой, синаповой, транс-цинамовой кислот. В корнеплодах катрана сердцелистного, кроме вышеуказанных, идентифрицировано хинную кислоту. В сырье обоих видов катрана не обнаружено галловой, гидроксифенилуксусной и транс-фреруловой кислот. Доминировала в подземных органах катрана сердчелистного и катрана коктебельского хлорогеновая кислота, содержание которой составляло 421,6 и 278,4 мкг/2 соответственно.

Выводы. Установлено наличие и методом ВЭЖХ-анализа определено количественное содержание в подземных органах катрана сердцелистного и катрана коктебельского индивидуальных гидроксикоричных кислот - хлорогеновой, кофеейной, р-кумаровой, сиринговой, синаповой, транс-цинамовой, а в подземных органах катрана сердцелистного - также хинной. Выяснено, что в исследуемом сырье обоих видов катрана доминирует хлорогеновая кислота, содержание которой составляет 421,6 и 278,4 мка/2 соответственно.

КЛЮЧЕВЫЕ СЛОВА: катран сердцелистный; катран коктебельский; подземные органы; гидроксикоричные кислоты; высокоэффективная жидкостная хроматография.

O. Ya. Skynchuk, S. M. Marchyshyn, L. V. Slobodianiuk, M. M. Kohut I. HORBACHEVSKY TERNOPIL NATIONAL MEDICAL UNIVERSITY

\title{
RESEARCH OF HYDROXYCINNAMIC ACIDS OF UNDERGROUND ORGANS OF COLEWORT HEART-LEAVED AND COLEWORT KOKTEBELICA
}

\author{
Summary \\ Introduction. The genus Crambe L. (colewort) belongs to the family Brassicaceae and has 44 species. In the
} flora of Ukraine there are 8 species of the Crambe L. genus, in the steppe zone grows 6 . The scientific name of the genus comes from the Greek word "krambos", which means "dry". In folk medicine, colewort have long been used as an antibacterial, antiviral, antiscorbutic, wound healing agent. Colewort is known mainly as a spicy and vegetable culture. The vegetative part of the plant is appreciated in animal husbandry as nutritious fodder for large and small cattle, and colewort seeds, containing up to $45 \%$ of fatty oil, serve as raw material for technical oil, wax, various fuels and lubricants. Thus, the genus Crambe L. is promising due to its nutritional, decorative and medicinal properties, etc. Crambe plants belong to medicinal crops, although they are not included in the pharmacopoeial lists of official medicine. Plants of the genus Crambe L. are poorly studied. Therefore, it is important to study the biologically active substances of two species of the genus Crambe L. - colewort heart-leaved (Crambe cordifolia Stev.) and colewort Koktebelica (Crambe koktebelica (Junge) N. Busch), which determine its pharmacological activity.

The aim of the study - to establish the presence and quantify the content of hydroxycinnamic acids in the underground organs of colewort heart-leaved and colewort Koktebelica by HPLC.

Research Methods. The content of phenolic compounds was determined by high performance liquid chromatography (HPLC).

Results and Discussion. The quantitative content of chlorogenic, caffeic, syringic, p-coumaric, trans-ferulic, sinapic and trans-cinnamic acids was detected, identified and established by HPLC in the underground organs of colewort heart-leaved and colewort Koktebelica. In addition to the above, quinic acid was identified in the roots of colewort heart-leaved. No gallic, hydroxyphenylacetic or trans-ferulic acid were found in the raw materials of both types of colewort. Chlorogenic acid was dominant in the underground organs of colewort heart-leaved and colewort Koktebelica, the content of which was $421.6 \mu \mathrm{g} / \mathrm{g}$ and $278.4 \mu \mathrm{g} / \mathrm{g}$, respectively.

Conclusions. The presence and method of HPLC analysis determined the quantitative content in the underground organs of colewort heart-leaved and colewort Koktebelica of individual hydroxycinnamic acids - chlorogenic, caffeic, p-coumaric, syringic, sinapic, trans-cinnamic. In the underground organs of colewort heart-leaved quinic acid was also determined. It was found that the studied raw materials of colewort heart-leaved and colewort Koktebelica is dominated by chlorogenic acid, the content of which was $421.6 \mu \mathrm{g} / \mathrm{g}$ and $278.4 \mu \mathrm{g} / \mathrm{g}$, respectively.

KEY WORDS: colewort heart-leaved; colewort Koktebelica; underground organs; hydroxycinnamic acids; HPLC.

Отримано 02.11.20

Адреса для листування: С. М. Марчишин, Тернопільський національний медичний університет імені І. Я. Горбачевського мОз України, майдан Волі, 1, Тернопіль, 46001, Україна, e-mail: marchyshyn@tdmu.edu.ua. 